\title{
The Art of Living is Living with the Art; Is it Essential that Bapedi People Are Able to Live with and Embrace the Past? Yes, Definitely
}

\author{
Morakeng Edward Kenneth Lebaka \\ Prof. Dr. University of Zululand, KwaDlangezwa Campus, \\ Faculty of Arts, Department of Creative Arts
}

\section{Abstract}

For many centuries, music has been used in different indigenous African religious rituals as part of communal and personal religious rites. In the Bapedi society, songs accompany every phase of the divination process and, also any other task which they perform communally, for example, ancestor veneration. The purpose of this study was to investigate how Bapedi traditional healers and their trainees create imprecatory songs, as well as their societal value. The main questions the study addressed are: a) how do Bapedi traditional healers create imprecatory songs; and b) what is the societal value of these songs in the Bapedi culture. The study used a naturalistic approach and the methods of data collection were video recordings of cultural and religious rituals, interviews and observations. The study has revealed that in the Bapedi society like in other African societies, narratives in imprecatory songs can be classified broadly into three, namely: segmental narrative; incremental cycle and multiple recycle forms. The results have also shown that Bapedi imprecation songs serve various functions such as education, upholding and promoting morals and customs through advice, insults and mockery. This paper is submitted for consideration for the ICMS XXV, 25th International Conference entitled "Ideas and Research on Recent Issues"; University of Southern California.

Keywords: Bapedi society, imprecatory Psalm-like texts, Bapedi culture, divination process, Bapedi traditional healers

\section{Introduction}

The purpose of this study is to describe the local wisdom of Bapedi people who are located in Greater Sekhukhune District Municipality, Limpopo Province in South Africa (see figure 1). Greater Sekhukhune District is a municipality inhabited by a group of people who are very strong in holding the tradition of their ancestors. Bapedi 
people have enriched their culture ${ }^{1}$ that has wisdom in the local knowledge system to maintain the rituals of their lives, as a harmonization of human, natural and environmental relations. They speak the language called Sepedi. It is one of the 11 official South African languages. Bapedi people have always managed to retain their cultural heritage. This society is not a primitive society or an isolated tribe, instead it is a society that has followed a modern lifestyle, but Bapedi people still maintain their customs and tradition, have a mindset that is far ahead, because they are rich in philosophical teachings and values that sublime and obedient to the norms, sociocultural values resulting from the decisions of their cultural heritage and identity. The above observations are supported by Civallero (2007, p.1), who defines heritage as a heterogeneous ensemble of environmental and cultural elements - material or not, that are transmitted from generation to generation, creating the grounds on which every person builds and orientates his identity and his vision of the world. According to Civallero, a number of things are included in this wide concept, for example, landscapes, sounds, objects, tools, pieces of work and buildings (2007, p.1). In his view, they are considered to play an active part in the memory of any community, representing the history of every human group, as well as making clear the elements used in the relationship with their physical environment and their magical-religious world (2007, p.1). Cavallero is convinced that besides giving people a feeling of continuity in relation to previous generations, these elements are also important for their identity and the safeguard of human diversity and creativity $(2007, \mathrm{p} .1)$.

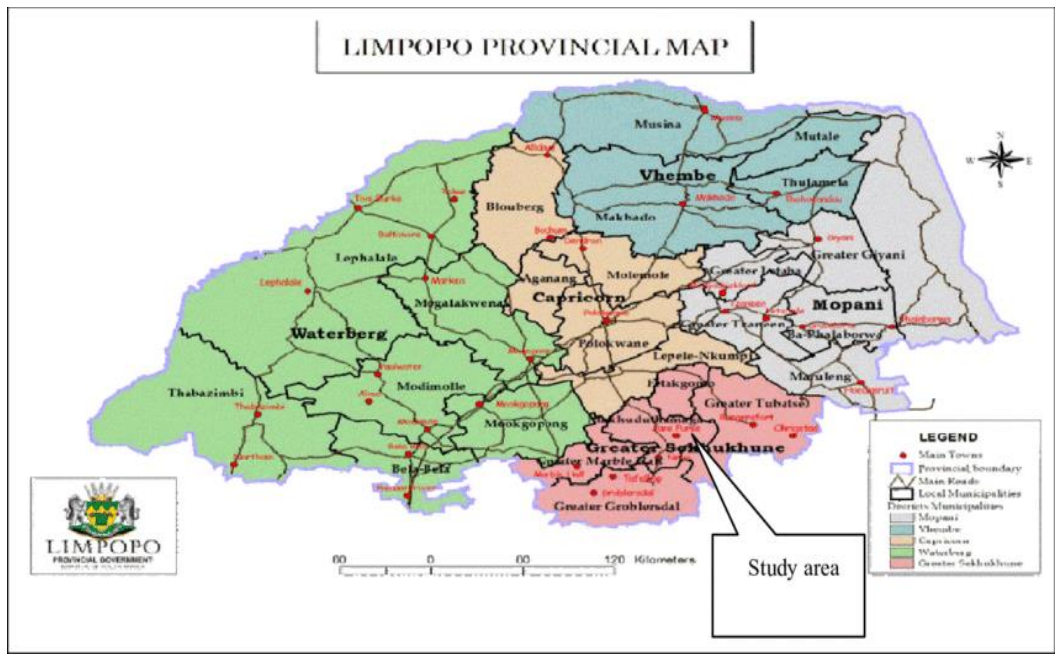

\footnotetext{
${ }^{1}$ Harashani (2018, p.52) describes value in a culture as a general opinion about something that is good, fair, polite and others. As with the norm, he opines that it usually consists of rules that apply to a particular culture $(2018$, p.52). In the same vein, Davies, et al $(2019$, p.2) observe that 'cultural' is therefore the way a society expresses itself, and the (multiple) ways that it articulates the human condition. Furthermore, Davies et al believe that science is an achievement of our societies, and its representation within public communication should be understood as being as much about contemporary popular culture as contemporary science $(2019, \mathrm{p} .3)$.
} 
Figure 1: Geographical Location Map of Limpopo Province showing Greater Sekhukhune District Municipality (N0.47).

https://en.wikipedia.org/wiki/Sekhukhune_District_Municipality\#/media/File:Map _of_South Africa_with Sekhukhune_highlighted (2011).svg [accessed 13 June 2021].

Bapedi tribe is one of the ethnic groups in South Africa who still retain cultural values and tradition of their ancestral heritage (see photo 1), and have a distinctive identity from the community. Bapedi people reject intervention from outsiders if it interferes and tarnishes the reputation and sustainability of the Bapedi culture.

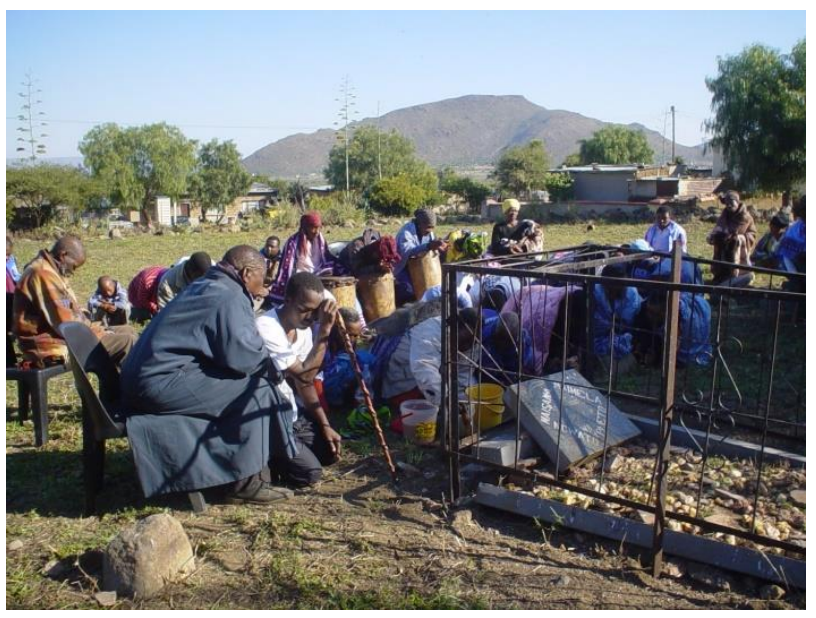

\section{Photo 1}

Traditional healers assisting the twins to communicate with their ancestors (Mashite village; Schoonoord, 29.09.2007), Photographer: Morakeng Edward Kenneth Lebaka.

Greater Sekhukhune District Municipality is comprised of several villages, and the highest leader in each village is known as kgoshi, who acts as a customary leader and caretaker of citizens who are handed down from generation to generation. One of the attractions of Bapedi tradition is the innovation and creativity of constructing traditional musical instruments, ancestor veneration and the belief in taboos and abstinence. Based on the many rules in indigenous Bapedi life, for Bapedi people the word culture refers to components such as values, habits adopted by society, for example, language, rules, tools and technology to make the things they use, traditional musical instruments inclusive and what they use and eat. For example, in the Bapedi culture women should stay at home, take care of the children, and men work for the living. Bapedi people believe that mutual cooperation, living in harmony and helping each other or one another promotes social cohesion, togetherness and humility. Individuals within the Bapedi society who want to win themselves, indulge in lust, pride and others are values that are considered unethical and not good for socialization. Cultural and religious beliefs are important in the Bapedi way of life. Like the ancient Israelites, these people have imprecatory songs. The question is: How 
are these songs created and what are their societal functions? In what follows, I briefly outline the theoretical framework of the study.

\section{Theoretical Perspective}

The theoretical framework of this study is based on John Dewey's theory of 'Art as Experience' (Dewey, 1980). Dewey used this theory to explore art's ontology, the interrelated processes of making and appreciation, the social role of the arts, communicative functions of the art and art's expression as experience. Dewey advocated that people are not isolated, not independent of other people and society. He believes that the life of the individual is tied to the nation's social life, to its nomos, to the spirit of its laws, and to its ethos, or the spirit of its culture (1884). For Dewey (1939/1989), culture is a term that refers to the complex of conditions by which people associate with one another, how they interact and live together. In his view, cultures are historical. He recognized that art functions as experience, but also emphasized that transformative experiences occur when people intuit new concepts, that occasion seeing in valued ways. Dewey further asserts that Art communicates moral purpose and education. He maintains that moral purpose is justifiable, art conveying messages that stimulate reflection on purposeful lives.

The theory focusses on art as a conscious idea and art's expression as experience. Based on these perspectives, Dewey's theory argues that in order for an experience to result in growth (i.e. for it to be an educative experience), it has to meet the dual criteria of continuing and of interaction (Stark 2020, p.122). He provides the most prolific insight of how humans are only human through their social interconnectedness with each other (Dewey, 1916). Dewey further asserts that the individual mind must be understood as a creative development of social life. In his view, the social is primary in that it comes first, whereas the development of the individual follows as a shadow of social relationships (1916). Like in this study, communal music-making in the Bapedi society is viewed as an essentially broad area of activity encompassing broad area of both social and frank issues of life (Lebaka 2017, p.204).

Dewey further posits that culture and history provide a malleable set of means (e.g. tools) that can be used to achieve immediate or easily viewed ends (Glassman 2001, p.5). In agreement Dewey and Vygotsky see the social as being of primary influence in the life of the individual (Glassman 2001, p.6), but Vygotsky (1987) sees tools and symbols as playing a much more active and determinate role in the lives of the individuals. This theory is adopted for this study because the ideologies of John Dewey are present within the Bapedi people's social and cultural context. Bapedi religious and cultural activities are supportive of Dewey's beliefs, advocacy and philosophy about social interactions and enculturation process in real life situations.

Consistent with Dewey's theory of 'Art as Experience', the transmission of indigenous music and other cultural and recreational activities among Bapedi people involves the transfer of knowledge and understanding between people. This theory attests to the 
observation that Bapedi people believe that mutual cooperation, living in harmony and helping each other or one another promotes social cohesion, togetherness and humility. The Bapedi context is ideal for this model because when the social, religious and cultural context of Bapedi real life situation is analyzed and examined through the framework of this study, the Bapedi tradition encourages teamwork a great deal. In traditional Bapedi society, life experiences are shared, whether they are sweet or bitter, painful or joyful. Things that are capable of causing pain and grief to families and clans are therefore issues of primary concern to Bapedi people, as well as traditional Bapedi music practitioners (Lebaka 2017, p.59). Like many other African societies, Bapedi people create music to accompany religious, cultural and social rituals, as well as to reflect on human experiences.

In the context of this study, the primary function of rituals and other cultural and recreational activities is to promote cohesion in the Bapedi society, to help a human being relate with himself, his neighbours and his environment. The theory is applicable to this study because in the Bapedi society, the learning process is a group activity; it is both a pleasure and a recreation rather than a chore. The group nature of the rehearsal is especially conducive to learning social, cultural and recreational activities while at the same time the nature of these activities' structure is such as to emphasize group rather than individual activity (Lebaka 2017, p.142). My interpretation of this model in relation to the Bapedi people's cultural context is that Bapedi people believe that mutual cooperation, living in harmony and helping each other or one another promotes social cohesion, togetherness and humility. In this study, the theory was used for reference while investigating how Bapedi traditional healers and their trainees create imprecatory songs, as well as their societal value. The theory also assisted in determining how songs with irony are used to advice, to insult, to mock, to provoke and to build moral in the Bapedi society.

Using John Dewey's theory of 'Art as Experience' as a framework, the following broad research questions were used to examine the experience shared among Bapedi people and perceptions that the art of living is living with the art: a) how do Bapedi traditional healers create imprecatory songs?; and b) what is the societal value of these songs in the Bapedi culture? This study may be beneficial for educators, sociologists and anthropologists interested in religious and cultural studies. In the next section the research strategy of the study is highlighted.

\section{Research strategy}

The study used a naturalistic approach and the strategies of data collection were observations, interviews, documentation and audio-visual materials. I observed Bapedi people's cultural and religious rituals. Most interviews were informal and spontaneous. Individual face-to-face, semi-structured interviews with fifteen (15) participants and three (3) focus groups discussions were held with knowledgeable elderly Bapedi people in order to understand Bapedi people's way of life. While this work remains chiefly a product of research field, it is complemented by a literature 
review. The idea was to find out what other scholars have discovered about indigenous knowledge in Africa. The design applied in this research is ethnography. The design is used to describe Bapedi culture and understanding of the way of life that comes from the views of the Bapedi people of Greater Sekhukhune District Municipality. In the next section the findings of the study are discussed.

\section{Results}

During my field research, it was observed that in the Bapedi culture like in other African societies, narratives in imprecatory songs can be classified broadly into three, namely: segmental narrative; incremental cycle ${ }^{1}$ and multiple recycle ${ }^{2}$ forms. For the purpose of this paper, I will discuss the segmental narrative form only. The segmental narratives may have four sections, namely: introduction, development, recapitulation and coda or conclusion (Idamoyibo 2005, p.33). The investigation has revealed that in the segmental narrative, themes are lyrically developed to enact a story. The story is built into segments that assume different forms. Each segment often introduces a new idea, though it might be related to the former part. The new sub-section could start with a solo statement and move to chorus, to conclude with strict antiphony.

The following song 'Leepo' is an example of this form. It has emerged from this study that Leepo is an imprecation song reflecting strong irony. This is a characteristic of all kinds of imprecatory songs in the Bapedi culture. Leepo is sung in irony about the people who do not love, remember, respect and honour their ancestors. Major characteristics found in this song are pun (lines 1-4). This section (Section A), forms the introduction of the narrative. The soloist presents textual-melodic statements to firmly establish the theme of the narrative. Section B (lines 5-8) illustrates segments of the narrative development. Within this section (lines 5-8), we find recycling of the rhythmic and melodic themes recurring with variations as new lyrics are continually being introduced. In this section the poet expresses confidence in her traditional healer 'Mmatshatshaila'. Section C (lines 9-11) has aspects of persona, lament and despair; development of the narrative. Section D (lines 12-14) has the highest form of recycling where the poet sets different poetic lines to the same thematic idea. This

\footnotetext{
1 According to Idamoyibo (2005, p.141), incremental cycle forms are those whose sections build up phrases in similar melodic fragmentation: in antecedent and consequent phrase forms. The lyrical theme is stated and developed in series of recycles, which contain several variations in the melody, depending on the variable metre presented by the text. The development of the theme involves changing both in motif and tonal centre. Song 'Leepo' is a long narrative which is comprised in this form.

2 Multiple recycle form is described by Idamoyibo (2005, p.149) as solo and chorus form, where the chorus is constant and the solos keep developing the theme further. This form occurs when the narrative theme that forms the first melodic sentence is relatively short. The lead singer often goes through it once or twice, depending on its initial length, and the receiver soloist provides the cue on which the entire song is recycled. If the song is recycled several times, the lead soloist and receiver soloist inter-change the solo statements for each recycle. Each soloist would feed in developmental statement twice and hand over to the other, while the chorus keeps the response going. It is this method of presentation that normally determines the entire length of any Bapedi composition in this form. Song 'Leepo' is an example of this form.
} 
section reflects strong irony. Section E (lines 15-17) marks the conclusion of the narrative, presented in a recycled solo and chorus responsorial style.

\section{Text and translation}

\section{Song with Irony: Leepo}

\begin{tabular}{|l|l|}
\hline Sepedi & English Translation \\
\hline Badimo ba nteile & The ancestors have punished me \\
\hline $\begin{array}{l}\text { Ke ile go botša Mmane, } \\
\text { Mmatšhatšhaila seapara tšhwene }\end{array}$ & $\begin{array}{l}\text { I will report to my aunt, } \\
\text { baboon skin }\end{array}$ \\
\hline Ke ra wena maphutha ditšhaba & $\begin{array}{l}\text { I am referring to you the nation's } \\
\text { comforter. }\end{array}$ \\
\hline O tla šia mang ge o phutha ditšhaba? & $\begin{array}{l}\text { Whom shall you leave out in your } \\
\text { mission of comforting the nations }\end{array}$ \\
\hline Ke motlokwa ke ngwana madimabe & I am the Tlokwa, the bad omen \\
\hline Tlogelang manyatša dingaka & $\begin{array}{l}\text { Ignore those who are undermining } \\
\text { traditional healers }\end{array}$ \\
\hline A hleng batlo šala ba ehwa & They shall die \\
\hline $\begin{array}{l}\text { Etlang le bone dingaka tsa go tsoša } \\
\text { nna, kgole mabitleng }\end{array}$ & $\begin{array}{l}\text { Come and see traditional healers who } \\
\text { raised me from the grave }\end{array}$ \\
\hline Lešaba le ile & $\begin{array}{l}\text { My friends and relatives are gone } \\
\text { (dead) }\end{array}$ \\
\hline Ka go nyatša mangaka & $\begin{array}{l}\text { Because of undermining traditional } \\
\text { healers }\end{array}$ \\
\hline Ba ile mašabašaba & They are gone \\
\hline Lešaba la gešu le tšhabetše tumelong & $\begin{array}{l}\text { Most of the people have gone to the } \\
\text { missionary and indigenous churches }\end{array}$ \\
\hline Le tšhaba go epa digwere & $\begin{array}{l}\text { They are scared of digging out } \\
\text { medicines }\end{array}$ \\
\hline A hleng ba tšhaba go ba dišuputšane & They do not want to be dirty \\
\hline Dikolobe di epa digwere & Just like pigs as they dig out the roots \\
\hline Ba leswa ke go bea meeta hlogong & $\begin{array}{l}\text { They are fond of putting their pots on } \\
\text { their heads }\end{array}$ \\
\hline Ba ile, ba tšhaba go rapela mabitla & $\begin{array}{l}\text { They are dead, because they are scared } \\
\text { of venerating their ancestors. }\end{array}$ \\
\hline
\end{tabular}

The song was recorded by the author on a field trip at malopo ritual held at Dingwane village, Greater Sekhukhune District Municipality-Limpopo Province in May 2003.

The above imprecation song reflects strong irony about people who undermine traditional healers as well as their ancestors. It has emerged from this study that Leepo is a poem in a narrative form. The poet is a woman. Pun is a figure that is used 
to express double meaning. In line 1 we find an expression ('The ancestors have punished me'). The poet discloses her problem to the audience, saying 'badimo ba nteile' ('The ancestors have punished me'). This expression would normally be understood that the ancestors are harassing me. The second meaning suggests that the ancestors are making life difficult for me. In this context the poet implies that the ancestors have no sympathy on her, they want her to suffer.

In lines 2-3 the poet uses an ironical figure to suggest that her aunt 'Mmatšhatšhaila' is a powerful and helpful traditional healer. She expresses this (line 2) by saying 'seapara tšhwene' ('who is clad in a baboon skin'). In the Bapedi society only powerful or senior traditional healers could be clad in baboon skin while dancing in a malopo ritual or during the divination process. It is believed that from all the animals the baboon is the most important and favourite animal for traditional healers to perform their divination and healing processes. As Madikedike Simon Sete explained (22 May 2004) that, even though other animals are important, the baboon is regarded as the most important because its physical features look the same as those of a human being. That is why traditional healers make use of many divination bones from the baboon. Other bones used by Bapedi traditional healers for divination are from the dog, pig, jackal, cow, goat and sheep (Mahlase 1997, p.66-77).

The poet in this context however implies that she is suffering from ancestral spirits. This is the consequence of the punishment by the ancestors. Therefore, she will report her problems to her aunt 'Mmatšhatšhaila' to plead with the ancestors on her behalf for a speedy recovery. The poet is convinced that 'Mmatšhatšhaila' would draw her closer to the ancestors for recovery: 'I am referring to you, the nation's comforter' (line 3). The tone of the poet in line 4 'whom shall you leave out in your mission of comforting the nations?' indicates how powerful, famous and helpful 'Mmatšhatšhaila' is in the Bapedi society.

In lines 9-11 the aspects of persona, lament and despair are important. Burton and Chacksfield $(1979$, p.9) define the term 'persona' as a useful term to describe a narrator or a character of whom a poem speaks in the first person. They argue that the persona is not the poet, but functions as a mask or disguise that the poet puts on for the purpose of enacting a poem in a narrative form. The persona is a common and prominent feature in Bapedi psalm like-songs and poetry. It appears in the first person pronoun such as 'I and We'. Bapedi singers (performers) use either of these personas to narrate events that took place, as if they are right at the scene of the incidents. In this way it looks real and more effective in the presentation.

In 'Leepo' the poet uses the persona to create various effects. She uses it in line 9 to portray the narrator as the victim and reporter of what happened between her and the ancestors. She continues the narrative with subtlety. In line 8 she uses the third person pronoun ' $n n a^{\prime}$ ('me') to suggest and transform the character of the narrator from being the reporter to being the protagonist who is involved in the encounter. In 
an ironical manner the poet adopts the persona again in line 3 by the second person 'wena' ('you') to reinforce the latter role.

The poet presents the narrative in the guise of the persona that changes roles. The opening 'ke ra wena maphutha ditšhaba' ('I am referring to you, the nation's comforter' in line 3) presents the narrator as an observer and reporter, but she is subsequently transformed to the protagonist (line 5) who was narrating the story of her own experiences. This change of tone by which the narrator assumes the position of the protagonist in disguise is a poetic technique adopted to create the mood and effect of a narrative being narrated by the affected person. This technique often intends to arouse emotions that could stimulate sympathy, in order to have more effect on the audience. Other people may then identify with the same role.

In lines 6-10 the poet uses irony to suggest that traditional healers are important, powerful and helpful. Irony is a style figure that means the direct opposite of what is said. The poet expresses this by saying that those who undermine traditional healers will die (lines 6-10). This implies that ancestors are not only protective but can also punish if their offspring defy their instructions. The family spirit normally protects all those in that family from harm, but if one of them transgresses, particularly by omitting a religious ritual, the spirit becomes annoyed and punishes the family by causing an illness or death of one or more of its members (Gelfand et al, 1985, p.31; Mőnnig 1967, p.54).

The poet also uses irony in lines 8-10. She tells the story of how traditional healers have rescued her from her severe pain and illness. The ironical statement 'come and see traditional healers who raised me from the grave' implies that the poet (patient) was in a comma or she was critically ill. 'From the grave' (line 8) does not really mean that traditional healers have rescued the poet physically from the grave, but it expresses in how a bad and serious state of death the poet was. The poem continues and states that her friends and relatives are gone (line 9). This ironical figure is employed to express her feelings and experiences as well as to describe the present situation. In traditional Bapedi society when someone so dear to one's heart dies, particularly in a sudden manner, the grief is expressed as something very cold. The affected persons (close associates) would normally say 'bohloko' meaning ('my condolence to you'). In the context of irony: different poetic lines to the same thematic idea in lines 12-14, the singers narrate the biography of people who undermine traditional healers and ancestors. They tell the audience of the people who have died as the consequence of undermining traditional healers and ancestors or looking down upon their culture. The irony here is that the singers are neither expressing their heartfelt condolences nor grief to the deceased but urging the audience to observe all the cultures and never ever forget their own. The message put across is also ironically directed to the audience that if they do not respect traditional healers, consult with them and venerate ancestors, shall die. 
The expression 'le ile' ('are gone'- dead in line 9), does not mean to visit but provides more information on the real death as the consequence of undermining traditional healers (line 10). Her friends and relatives are really dead as the consequence of witchcraft because they do not want to consult with traditional healers for divination, prevention and protection (line 11). Lines 12-17 reflect strong irony, which is intermixed with a plea for a hearing. The poet's expressions (lines 12-17) suggest that most people (in the Bapedi community) are indoctrinated by the missionaries. They have forgotten about their culture and they have abandoned their ancestors. The expression 'le tšhaba go epa digwere' ('they are scared of digging out medicines') in line 12 implies that the indoctrinated people oblige and comply with their church doctrines (dogmas) which prohibit people from observing their tradition, like ancestor veneration, circumcision, polygamy, etc. (Amanze 1998, p.52; Mugambi 2005, p.532).

A metaphor describes the indoctrinated people (line 14). The poet expresses in line 15 that 'dikolobe diepa digwere' ('just like pigs as they dig out the roots'). This implies that the indoctrinated people do not want to be like pigs which are fond of digging the roots. She deliberately raises the characters (pigs), because pigs like digging. The poet personify the pigs as human beings. In the Bapedi society personification is so common that it has become a commonplace expression in everyday language of the society. In line 16 the poet uses of an expression: 'ba leswa ke go bea meeta hlogong' ('they are fond of putting their pots on their heads'). The expression literally means that Bapedi people very often fetch water with their pots. In the Bapedi society the expression suggests that the indoctrinated people are good in fetching water with their pots but cannot dig out medicines. The seeming contradiction is that 'digging out the roots' (line 15) has nothing to do with 'putting the pots on the heads' (line 16). In line 17 'ba ile, ba tšhaba go rapela mabitla' ('they are dead, because they are scared of venerating their ancestors'), the poet and performers (solo and chorus) express their disappointment ironically. Apart from expressing disappointment, the poet and performers provide advisory information to the audience, that they should honour, remember and respect their ancestors.

The climax of this song is the ending: those who undermine traditional healers and who are not willing to venerate ancestors, are and/or will be punished by death. They are dead (line 17). The aid of the ancestral spirits is sought because, the susceptibility of earthly descendants to disease depends largely on their ancestral spirits (Krige and Krige 1954, p.61). Their favour could provide their dutiful descendants with immunity from the ill-effects of sorcery and witchcraft. Ancestral spirits are not only punishing ancestors but are also the guardians of morality in the family circle (Magesa 1997, p.48). Ancestors see to it that there is no permanent feud between earthly members of the family. They have unlimited powers over the lives of the living. There are no restrictions to either the chastisement or the blessings that they can confer on their descendants. Ancestors in the Bapedi society, like in African traditions have 
power over life and death, over sickness and health, and over poverty and prosperity (Nthoi 1995, p.50; Parrinder 1976, p.58).

\section{Societal Function}

In answering the question 'What is the role of imprecatory songs in the Bapedi culture' during interviews, it was established that imprecation songs are deliberately sung to advice, to insult, to mock and to provoke. They are recited as the consequence of avenge or being bully, being selfish, naughty or jealous. In most cases members of the Bapedi tribe sing imprecatory songs to build moral in the society. For example, if a girl or woman is a prostitute, whenever people see her, they will sing an imprecation song, not necessarily to mock her, but to advise her to improve on her lifestyle. After listening to the song about her, she will hopefully change or improve on her lifestyle. In consonant with these observations, Mataira (2000, p.28) confirms that the songs of adultery contain derogatory references, slanders and sneers directed at others. He maintains that the songs use terms aimed to stir emotions and are composed with the deliberate intent to denigrate. He is of the opinion that songs that touch on adultery are accompanied by facial gestures; gesticulative hand movements, provocative stances and intimidating stares interplayed with insults.

Investigation has also revealed that imprecation in the Bapedi culture is used with regard to alcohol abuse, prostitution, etc. Apart from being an expression of disappointment, imprecation provides advisory information to the subject to improve on his/her living habits (Idamoyibo 2005, p.141). Imprecation songs can also be sung to a man who is an alcoholic, advising him to reduce his drinking habits. This view is supported by Mőnnig (1967, p.50-51) endorses this observation by stating that in the Pedi culture, when a man is under the influence of alcohol or wild hemp (cannabis indica), his seriti (dignity) and reputation are tarnished. People will say of a friend who is drunk: "Thaka ya rena mamohla ga a tee, ba babedi" This friend of ours isn't one, they (man and alcohol) are two. The expression simply means the man is drunk. In sum, Bapedi imprecation songs are sung to change peoples' behaviour as well as to build their identity.

\section{Discussion}

The results yielded thus far have shown that in singing imprecatory songs Bapedi singers do not conceive their poetic lines in writing, but follow the grammatical structure of the Bapedi language to ensure that the lyrics of their songs make poetical and melodical meaning. Based on the findings of this study, it is evident that in the Bapedi culture imprecation is employed for the censure of drunkenness, abuse and prostitution. These songs are developed thematically. It would seem that other poetic devices which are commonly utilised in imprecatory songs include irony. In this way sanctions are advanced on erring members of society. It has emerged from this study that confidence in human intermediaries and ancestors is also expressed. To that end Bapedi cultural and religious traditions are rehearsed and inculcated in the community. From this study, it is evident that disregard for Bapedi traditions and 
custodians of customs is disastrous as it may invoke ancestral punishment. We observe in the present study that Bapedi imprecation songs serve various functions such as education, upholding and promoting morals and customs through advice, insults and mockery. They emphasize the corrective role of judgments and the need to abide by communal values in order to experience well-being. Indications from the investigation suggest that Bapedi people should perpetuate their cultural and religious practices to preserve the Bapedi cultural heritage and for the benefit of the next generation.

During observations and interviews, it was established that although protective, ancestors are capable of vindictiveness. Thus, those who rebel against aged customs such as Christians who refuse to venerate their ancestors are in danger of death. Disobeying traditional healers may also elicit punishment. Bapedi imprecatory songs are aimed at providing advice. They function to insult, mock, and provoke the defiant members of the society. In this way morals are promoted and maintained. Vices such as adultery, drunkenness, use of wild hemp and dishonouring of ancestors and traditional healers are censured. The results yielded thus far suggest that functionally therefore, imprecatory songs in the Bapedi culture serve divergent purposes.

An interesting dimension of this study is the creation of imprecatory songs within the Bapedi cultural context. Reviewing the results thus far, it is clear that in the Bapedi culture, irony is a style figure that means the direct opposite of what is said. The results of this study show vividly that Bapedi people use persona to create various effects. The results have also demonstrated that in the Bapedi society like in other African societies, narratives in imprecatory songs can be classified broadly into three, namely: segmental narrative, incremental cycle and multiple recycle forms.

\section{Conclusion}

This paper illustrates that within the Bapedi cultural context, songs with irony, such as 'Leepo' have the potential to serve various functions such as education, upholding and promoting morals and customs through advice, insults and mockery. On a more positive note, irony practices illustrated in this paper could easily be translated into many pedagogical contexts. For example, they could be used to create direct experiences and explore culture within the society, but could also be employed to remind Bapedi people not to forget about their roots. The results have revealed that Bapedi people enjoy their art, and they remain loyal and obedient to their ancestors, such as carrying out various rituals and ceremonial activities with applicable conditions.

On the basis of the findings and discussions of this study, it is arguable that Bapedi society is an indigenous community that has local knowledge and wisdom that can be applied to daily life through various rituals and ceremonies. Indications from the investigation suggest that Bapedi people work collaboratively and as an expression of gratitude to their ancestors, they have full confidence in their ancestors, and have the art of communicating with them for peace, safety and welfare. It has emerged from 
this study that the local knowledge system of Bapedi people comprises patterns of collective behaviour that they have thus far sustained. As oral traditions play an important role in knowledge production, preservation and dissemination, a recommendation is hereby made that Bapedi people should continue perpetuating their cultural practices and art of living by embracing the past and observing their culture. There is no better time to start reviving and preserving Bapedi culture than now.

As a way of redeeming the loss and reviving cultural heritage and identity of the Bapedi people, it is recommended that revitalization of a local knowledge system for indigenous people especially in the learning area 'Creative Arts' at the primary school should be a necessity, as it will serve as the foundation of national identity, but shall also guide students to be democratic and adaptive towards social and cultural dynamics.

\section{References}

[1] Ajah, P.0. 2004. Stepping into comprehensive Philosophy. Benin: Timeless Publications.

[2] Akivaga, S. K. and Odaga, A. B. 1982. Oral Literature. A School Certificate Course. Nairobi: East African Educational Publishers.

[3] Civallero, E. 2007. Traditional games, music and oral tradition. Intangible tools in multicultural libraries. In IFLA (ed.), Proceedings of IFLA Satellite Meeting 2007. Conference on Innovative Multicultural Library Services for All (pp. 1-17), Pretoria, South Africa; 15-17 August 2007.

[4] Bakare, O. R. \& Mans, M. 2003. 'Dance Philosophies and Vocabularies'. In: Anri Herbst, Meki Nzewi \& Kofi Agawu (eds). Musical Arts in Africa, 215-235. Pretoria: Unisa Press.

[5] Burton, S. H. and Chacksfield, C. J. H. 1979. African Poetry in English: an introduction to practical criticism. London: Macmillan Press.

[6] Davies, et al. 2019. Science stories as culture: experience, identity, narrative and emotion in public communication of science. Journal of Science Communication, Volume 18, Number 5, pp. 1-17.

[7] Dewey, J. 1916. Democracy in education. New York: Free Press.

[8] Dewey, J. 1980. Art as experience. New York: Perigee Books. (Originally published 1934).

[9] Dewey, J. 1989. Freedom and Culture. Buffalo, NY: Prometheus Books. (Originally Published 1939).

[10] Dewey, J. 1884. The new psychology. Andover Review 2, pp. 278-289.

[11] Floyd, M. 2000. 'Maasai, Rituals and Identities'. In: Harvey Graham and RallsMacLeod Karen (eds). Indigenous Religious Music. Aldershot: Ashgate Publishing Company.

[12] Glassman, M. 2001. Dewey and Vygotsky: Society, Experience, and Inquiry in Educational Practice. Educational Researcher, Vol. 30, No. 4, pp. 3-14. 
[13] Harashani, H. 2018. Local wisdom of Kampung Naga in the Era of Globalization. Journal of Humanities and Social Studies, Volume 02, Number 01, pp. 51-54.

[14] Idamoyibo, I, O. Igoru Music in Okpeland: A Study of its functions and compositional techniques. Unpublished Doctoral thesis. Pretoria: University of Pretoria.

[15] Krige, E. J. 1937. 'Individual Development'. In: I. Schapera (ed). The Bantuspeaking Tribes of South Africa. London: Routledge.

[16] Lebaka, M.E.K. 2017. Transmission Processes of Indigenous Pedi Music. Jyvàskylä, Finland: University Library of Jyvàskylä.

[17] Levine, L. 2005. The Drumcafe's Traditional Music of South Africa. Johannesburg: Jacana Media.

[18] Mashau, T. D. 2005. Love, Courtship and Marriage. Biblical solutions to problems confronting African youths in the $21^{\text {st }}$ century. Pretoria: V \& R Printing.

[19] Merriam, A. P. 1964. The Anthropology of Music. Evanston: North Western University Press.

[20] Mitzlaff, U. 1998. Maasai women: Life in a Patriarchal Society. Dar es Salaam: Tanzania Publishing House.

[21] Mugambi, J.N.K. 2005. 'Christianity and the African Cultural Heritage'. In: Ogbu U. Kalu (ed). African Christianity. An African Story, 516-541. Pretoria: University of Pretoria.

[22] Nang'oli, M. 2000. No more Lies about Africa. East Orange. New Jersey: African Heritage Publishers.

[23] Nzewi, M.E. 1998. 'Music Teaching and Learning in African Cultures'. In: Caroline van Niekerk \& S. Torta (eds). 23 ${ }^{\text {rd }}$ ISME Selected Conference proceedings: abstracts of papers, workshops and demonstrations, 132-139. Pretoria: Unisa Press.

[24] Orawo, C. N. 1998. 'Music education as a means of attaining insight in humanity'. In: Caroline van Niekerk \& S. Torta (eds). 23rd ISME Selected Conference proceedings: abstracts of papers, workshops and demonstrations, 142-148. Pretoria: Unisa press.

[25] Pitje, A.M. 1948. Traditional and Modern Systems of Male Education amongst the Pedi and Cognate Tribes. Pretoria: University of South Africa.

[26] Sekhukhune, P. D. 1988. Discourse Analysis and Speech Varieties in Northern Sotho: A Sociolinguistic Study. Unpublished Master's thesis. Pietersburg: University of the North.

[27] Stark, J. 2020. Dewey's Theory of Experience: A Theoretical Tool for Researching Music Teacher Learning. Action, Criticism, and Theory for Music Education 19 (1):118-152.

[28] Uzoigwe, J. 1998. Ukom Songs: Texts and Transcriptions. Okigwe: Fasmen communications. 
[29] Vygotsky, L. S. 1987. The collected works of L. S. Vygotsky: Vol. 1, Problems of general psychology. R. Rieber \& A. Carton (eds.), (N. Minick, Trans.). New York: Plenum Press. (Original work published 1934).

[30] Wanyama, M. N. 2005. Form and Content of African music: A Case study of Bukusu Circumcision Music. Unpublished doctoral thesis. Pretoria: University of Pretoria. 